\title{
DETERMINATION OF MECHANICAL PROPERTIES OF BIOLOGICAL MATERIAL OF ANIMAL ORIGIN
}

\author{
Gzik-Zroska B.*, Joszko K. ** Kawlewska E. ${ }^{* * *}$, Balin A. ${ }^{* * * *}$, \\ Karczewski J.******, Wyciślok P.*
}

\begin{abstract}
In this paper, it was described the experimental tests for animal's intestines, that is used in the meat industry as the natural, edible casings. It was carried out the static tensile test in the physiological chamber in three temperatures for 201 samples. The main aim of investigations was to evaluate the influence of technological operations on the intestines' mechanical properties. Obtained results can provide a basis for comparative analysis both for animal and human tissues.
\end{abstract}

\section{Keywords: Animal's intestines, Static tensile test, Influence of temperature, Breaking strength,} Young's modulus.

\section{Introduction}

The determination of mechanical properties in biological materials is a crucial but also relatively complicated task. The knowledge of mechanical properties is important in the process of modeling biological structures, verification of developed models and designing various types of technological processes (Gzik-Zroska et al., 2018, Ogurtan et al., 2001, Wolański et al., 2017). In biomedical investigations developing the research method and comparing research results is difficult due to the lack of clear standards that include the regulations for these kinds of experimental tests (Heijnsdijk et al., 2003). The scientists deal with conducting experimental research on biological tissues of both animal and human origin (Gzik-Zroska, 2016, Joszko, 2019, Milewski, 2012, Pezowicz, 2012). It requires them a lot of experience and at the same time knowledge about the anatomy and functioning of the particular tissues. The results of this type of research significantly contribute to the development of medicine. The research aimed at determining the mechanical properties of biological tissues for the meat or generally food industry is also carried out by other authors. In the article of Sobczak et al., 2014 mechanical properties of casings were determined for polyamide, collagen (caramel) and natural casings, before heat treatment, after smoking and after brewing.

Considering the above, the main aim of investigations was to evaluate the influence of technological operations on the intestines' mechanical properties. An attempt was made to develop the research methodology of experimental tests for determining the mechanical properties of an animal's intestines, which are used in the meat industry. Also, it was analyzed how the specific technological processes change the mechanical properties of tested tissues.

PhD. Eng.: Department of Biomaterials and Medical Devices Engineering, Silesian University of Technology, Roosevelta 40, 41-800, Zabrze, PL; bozena.gzikzroska@polsl.pl

** $\quad$ PhD. Eng.: Department of Biomechatronics, Silesian University of Technology, Roosevelta 40; 41-800, Zabrze; PL; kamil.joszko@polsl.pl

*** PhD. Eng.: Department of Biomechatronics, Silesian University of Technology, Roosevelta 40; 41-800, Zabrze; PL, edyta.kawlewska@polsl.pl

**** DSc Eng., prof PŚ: Department of Biomechatronics, Silesian University of Technology, Roosevelta 40; 41-800, Zabrze; PL, alicja.balin@polsl.pl

***** Department of Biophysics and Plant Morphogenesis, University of Silesia, 40-032 Katowice, PL, Poland;jerzy.karczewski@us.edu.pl

${ }^{* * * * * *}$ PhD. Eng.: University of Technology, 43 Rolna Street, 40-555 Katowice, PL, piotr.wycislok@gmail.com 


\section{Material \& methods}

The experimental tests were performed on the 201 animal's origin specimens - pork and sheep casings. The intestines were delivered from various producers (Fig. 1). There were specimens after two specific technological processes: soaking and calibration. Soaking in warm water is necessary to obtain optimal softness and tenderness. Calibration is the process, when the intestines are inflated with air to check for holes and then they are stretched and sized to the dimension of various pipes.

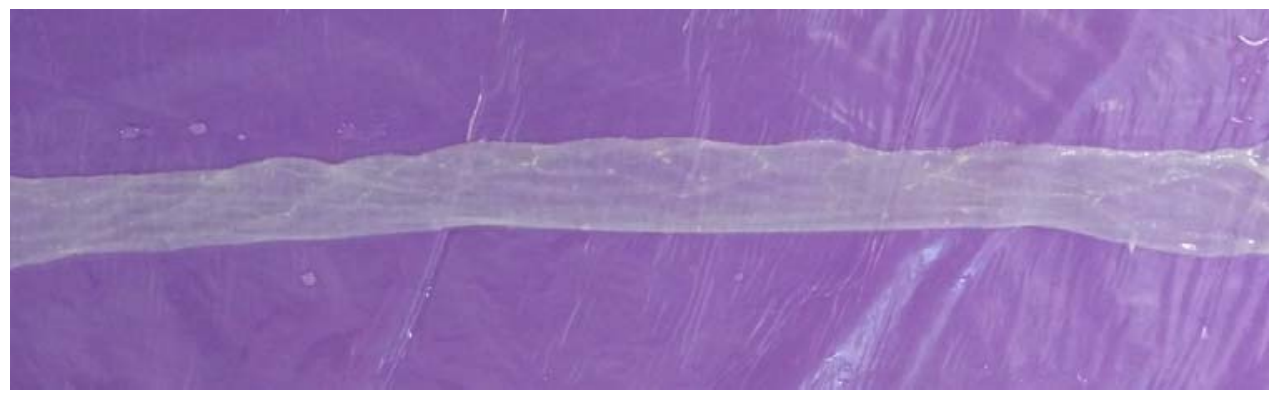

Fig. 1: Exemplary specimen of intestine.

All specimens were vacuum-packed in the salt solution. Directly before the static tensile test, the specimens were soaked in water for 1 hour, to remove salt from the tissue. Also, it was measured the length, width and thickness of all specimens. The tests were carried out in the physiological chamber, filled with distilled water at room temperature and at an elevated temperature: $30^{\circ} \mathrm{C}$ and $40{ }^{\circ} \mathrm{C}$. These boundary conditions were suggested by the producers.

The static tensile tests with the constant velocity $(10 \mathrm{~mm} / \mathrm{min})$ were performed on the MTS Insight machine and the specimens were mounted with the use of specially designed, dedicated grips (Fig. 2). The test continued until the sample was fractured in the vertical axis of the intestine.
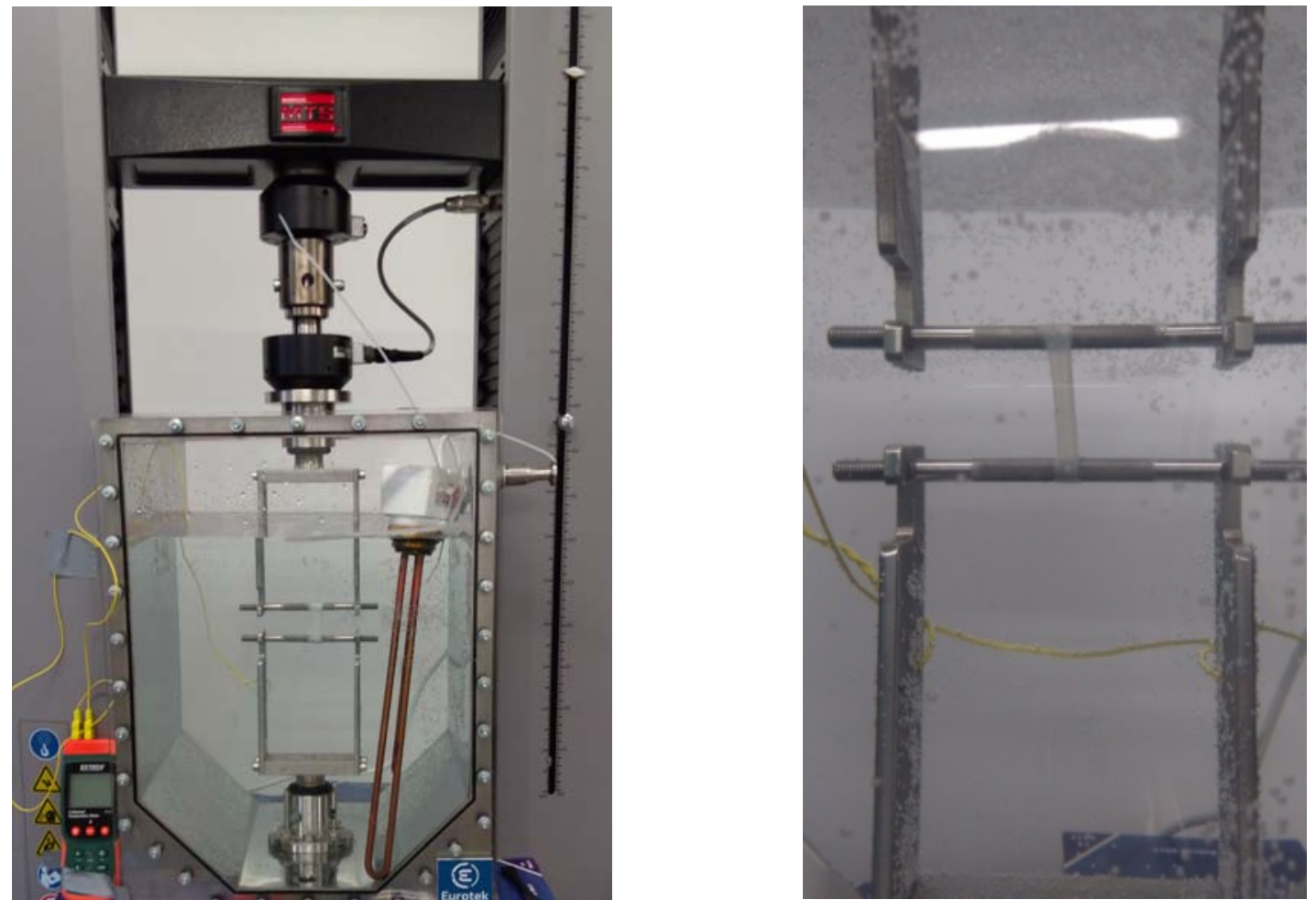

Fig. 2: Photographs of specimen, mounted in specially designed grips, immersed in a physiological chamber.

During the experiments, it was obtained the breaking force for each sample. Subsequently, the breaking stress and Young's modulus were read from the machine's reports. These parameters are calculated by machine, on the basis of the tangent of the angle of the proportional section in the stress-strain diagram. In the figures below (Figs. $3 \div 5$ ) it was presented the average values of all parameters, depending on the temperature. 


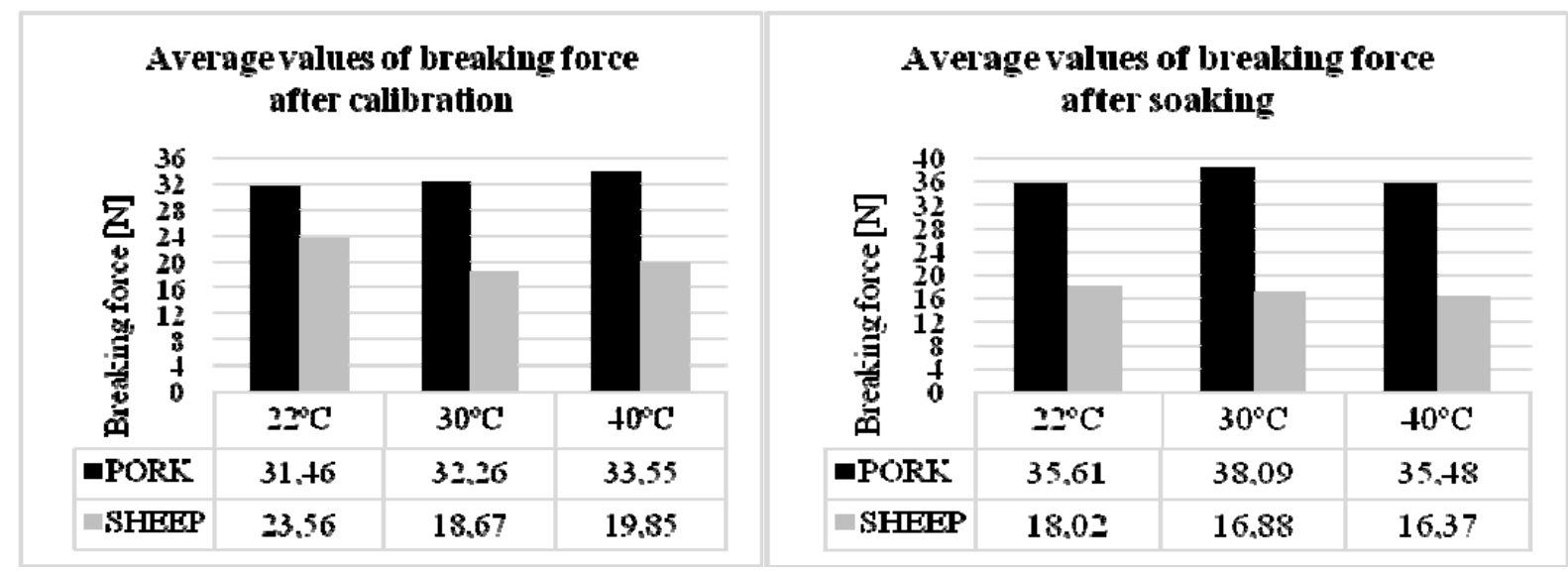

Fig. 3: Average breaking force values for pork and sheep casinos, obtained during tensile tests at the various temperatures.
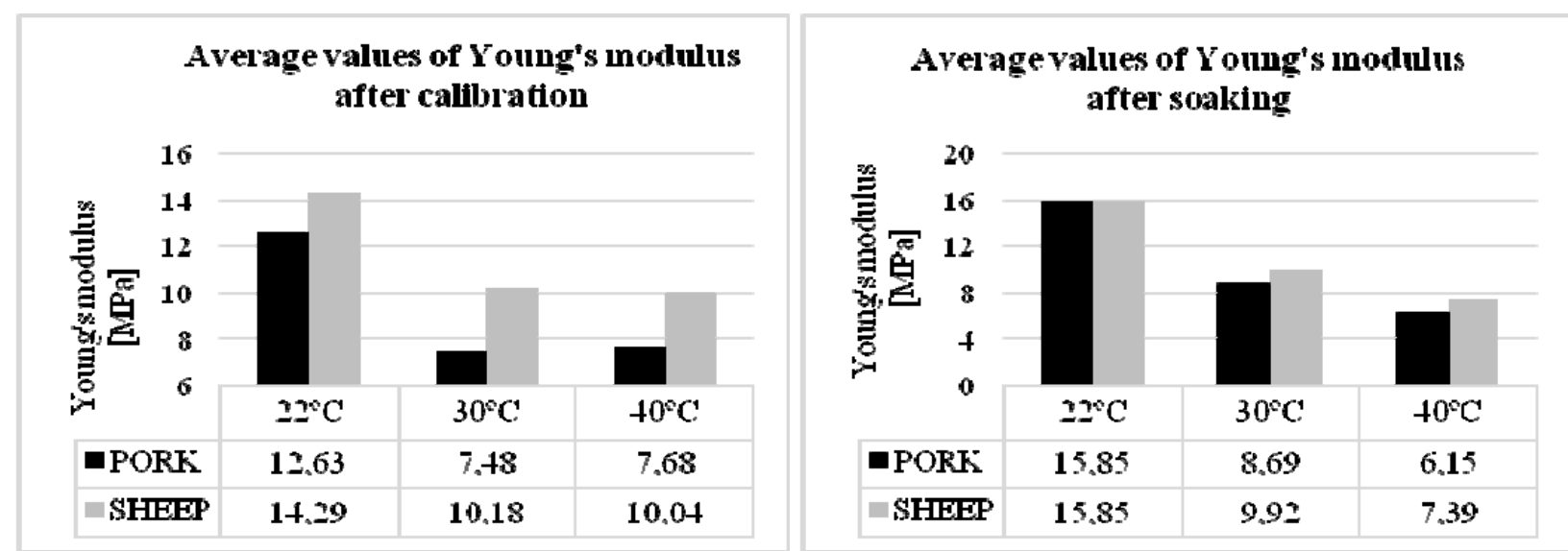

Fig. 4: Average Young's modulus values for pork and sheep casings obtained during tensile tests at the various temperatures.

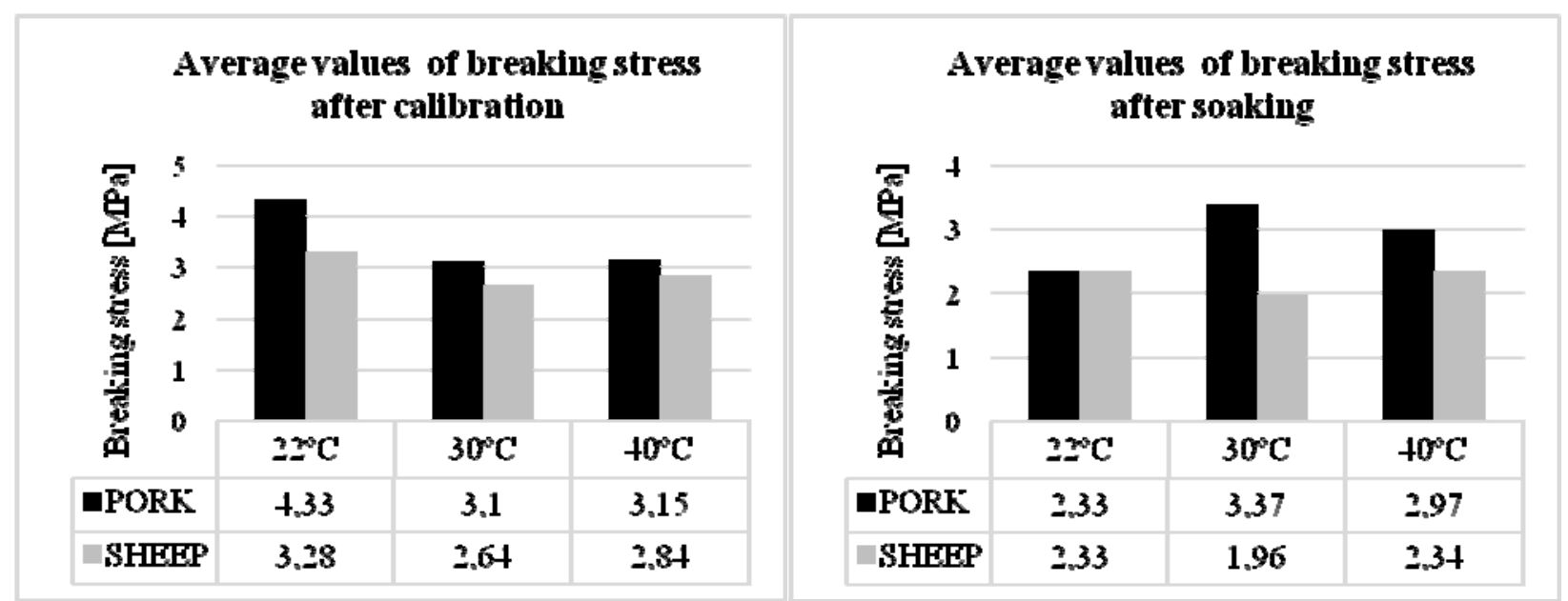

Fig. 5: Average breaking stress values for pork and sheep casings, obtained during tensile tests at the various temperature.

On the basis of obtained results it can be stated that both sheep's and pork's specimens have a higher Young's modulus at the room temperature than at an elevated temperature. The values obtained in temperatures $30{ }^{\circ} \mathrm{C}$ and $40{ }^{\circ} \mathrm{C}$ are very similar and significantly lower. For example, after calibration at the elevated temperature, Young's modulus of pork casings is about $40 \%$ lower and for sheep casing is about $30 \%$ lower. After soaking the difference is even greater, especially at $40{ }^{\circ} \mathrm{C}$, where the difference is about $61 \%$ for pork casings and about $54 \%$ for sheep casings. It was also observed the differences in stress values for individual temperatures (Fig. 4). 


\section{Conclusions}

Based on the performed researches it could be stated that the mechanical properties of intestines vary depending on the species from which they were prepared. Pork's intestines have both higher Young's modulus and breaking stresses than the sheep intestines. It is caused by the individual factors of each species and the various geometry. Subsequently, it can be stated that the technological processes and the elevated work of temperature have a negative influence on the strength properties. The next step of investigations is the statistical analysis of results presented in this paper.

The research carried out as part of this work can be useful not only for the meat or food industry but also in medicine. Animal intestines are very often accepted as models of the human intestine (Cadena et al., 2005, Dou et al., 2006). In order to correctly determine which animal intestine may represent the human intestine, it is necessary to know their mechanical properties. Any study performed on biological material is valuable due to the introduction of some kind of standardization in research on this type of material. Sharing this knowledge in the scientific world leads to the development of a kind of norms defining how to handle biological material and allows to determine how various external factors can affect its internal structure.

\section{Acknowledgement}

The presented results are the result of the implementation of a research project at JELUX Polska sp. $\mathrm{z}$ o.o. "Introduction of a process innovation to business activity consisting in the automation of the production of natural casings from intestines and product innovation in the form of a new assortment of welded intestines", co-financed by the Polish National Center for Research and Development (contract number: POIR.01.01.01-00-0207 / 17-00).

\section{References}

Cadena C., Tabima D. M., Briceno J. C. (2005) Tensile mechanical properties of porcine small intestine submucosa scaffolds: effect of orientatoin and number of layers. ASAIO journal: a peer-reviewed journal of the American Society for Artificial Internal Organs vol. 51, no. 2.

Dou Y., Fan Y., Zhao J., Gregersen H. (2006) Longitudinal residual strain and stress-strain relationship in rat small intestine. Biomed Eng Online, 5: 37.

Gzik-Zroska B., Joszko K., Wolański W., Gzik M. (2016) Development of new testing method of mechanical properties of porcine coronary arteries. Advances in Intelligent Systems and Computing; vol. 472, 2194-5357, doi: 10.1007/978-3-319-39904-1_26.

Gzik-Zroska B., Joszko K., Wolański W., Kawlewska E., Burkacki M., Suchoń S. (2018) Application of digital image correlation to determine the mechanical properties of biomaterials. In: Proc. of Internat. Conf. Engineering Mechanics, Eds. Fisher C., Naprstek J., vol. 24, pp. 277-280.

Heijnsdijk E. A. van der Voort, M., M. de Visser, H. Dankelman, J. and Gouma D. J. (2003) Inter- and intraindividual variabilities of perforation forces of human and pig bowel tissue. Surg Endosc 17: 1923-1926 doi: 10.1007/s00464-003-9002-3.

Joszko K., Gzik-Zroska B., Kawlewska E., Klama-Baryła A., Suchoń S., Burkacki M, Wolański W. (2019) Evaluation of the impact of decellularization and sterilization on tensile strength transgenic porcinedermal dressings. -Acta Bioeng. Biomech. vol. 21, no. 3, pp. 1-15, doi 10.5277/ABB-01382-2019-02.

Milewski G., Hille A. (2012) Experimental strength analysis of orthodonticextrusion of human anterior teeth, Acta Bioeng. Biomech, 14 (1), pp. 15-21.

Ogurtan Z., Gezici M., Kul M., Ceylan C., Alkan F. (2001) Compararative study of bursting and tensile strengths of digestive tract in the dog. Application to esophago-intestinal sutures. Revue Méd. Vét., 152, 6, 491-494.

Pezowicz C., Głowacki M. (2012) The mechanical properties of human ribs in young adult, Acta Bioeng. Biomech., 14 (2), 53-60. doi: 10.5277/abb120208.

Sobczak P., Żukiewicz-Sobczak W., Panasiewicz M., Zawiślak K., Mazur J (2014) Ocena czystości mikrobiologicznej farszu parówek oraz cech jakościowych wykorzystanych osłonek. Polish Journal of Food Engineering, 2 (10), 30-33, (in Polish).

Wolański W., Gzik-Zroska B., Joszko K., Gzik M., Sołtan D. Numerical Analysis of Blood Flow Through Artery with Elastic Wall of a Vessel. In: Gzik M., Tkacz E., Paszenda Z., Piętka E. (eds) Innovations in Biomedical Engineering. Advances in Intelligent Systems and Computing, vol 526. Springer, Cham. doi:10.1007/978-3-31947154-9_23. 